\title{
24. NUMERICAL AGES OF MAGNETOSTRATIGRAPHICALLY CALIBRATED BIOSTRATIGRAPHIC ZONES1
}

Kenneth J. Hsü, Geologisches Institut, Eidgenössische Technische Hochschule Zürich, CH-8092 Zürich, Switzerland Stephen F. Percival, Jr., Mobil Oil Exploration and Producing Services, Dallas, Texas

Ramil C. Wright, Exxon Production Research Co., Houston, Texas

and

Nikolai P. Petersen, Institut für Allgemeine und Angewandte Geophysik, Universität München, Munich, Federal Republic of Germany

\begin{abstract}
Most Cenozoic nannofossil and many foraminiferal zonal boundaries have been accurately determined and magnetostratigraphically calibrated at five Leg 73 boreholes. The numerical ages of the boundaries were computed by assuming a linear seafloor spreading rate and a radiometric age of $66.5 \mathrm{~m} . \mathrm{y}$. for the Cretaceous/Tertiary boundary. Alternative magnetostratigraphic ages (given below in parentheses) were obtained by adopting a $63.5 \mathrm{~m}$.y. age for the Cenozoic. Our data confirm previous determinations of the Pleistocene/Pliocene boundary at $1.8(1.7) \mathrm{m} . \mathrm{y}$. and of the Pliocene/Miocene boundary at 5.1 (5.0) m.y. The Miocene/Oligocene boundary is placed within Chron C-6C and has a magnetostratigraphic age of 23.8 to 24.0 (22.7 to 22.9$) \mathrm{m}$.y. The Oligocene/Eocene boundary is also very precisely located within Chron C-13-R, with a magnetostratigraphic age of 37.1 to 37.2 (35.5 to 35.6) m.y. The Eocene/Paleocene boundary should be located within an uncored interval of Chron C-24 and have a magnetostratigraphic age of 59.0 (55.4) \pm 0.2 m.y.

The general accord of the magnetostratigraphic and radiometric ages supports the hypothesis that the seafloor spreading rate was linear during the Cenozoic. Two possible exceptions are noted: the middle Miocene radiometric ages are a few million years older, and the early Eocene radiometric ages are several million years younger, than the corresponding magnetostratigraphic ages.
\end{abstract}

\section{INTRODUCTION}

We achieved during the Leg 73 drilling a correlation between the magnetostratigraphy of the Cenozoic sedimentary sequence and the seafloor magnetic anomalies, and we also demonstrated that the rate of seafloor spreading has been linear or nearly linear during the Cenozoic (see site chapters for Sites 519-524). By using a radiometrically determined date for the beginning of the Cenozoic, the ages of the magnetostratigraphic epochs or chrons can be computed to correlate to the width of the linear anomalies. The time scale established by LaBrecque et al. (1977) was based on a 65.0 m.y. age for the beginning of the Cenozoic Era. The time scale adopted by Tauxe et al. (this vol.) for the magnetostratigraphy of the Leg 73 sediments assumes a $66.5 \mathrm{~m}$.y. age. The absolute ages of the chrons thus determined will be the magnetostratigraphic ages referred to in this chapter unless otherwise designated. Another radiometric age for the Cretaceous/Tertiary boundary is 63.5 m.y. (Lerbekmo et al., 1979). The absolute ages of chrons based on that age are referred to as alternative magnetostratigraphic ages and are given in the text and illustrations in parentheses.

The position of the lowest occurrences (LOs) and highest occurrences (HOs) of various foraminiferal and nannoplankton species has been correlated to magnetostrati-

\footnotetext{
${ }^{1}$ Hsï, K. J., LaBrecque, J. L., et al., Init. Repts. DSDP, 73: Washington (U.S. Govt. Printing Office).
}

graphic chrons so that the numerical ages of those datum levels could be obtained. Unless the ranges of those fossil occurrences are demonstrably modified by dissolution or influenced by migration, we shall consider the lowest and highest occurrences to be the first and last appearance datums (FADs and LADs). Since many of those event markers have been used for biostratigraphic zonations, we have been able to obtain magnetostratigraphic ages for various zonal boundaries. The nannofossils in the Leg 73 sediments are well preserved on the whole, so all except a few of the Cenozoic nannoplankton zones (as defined by Martini, 1971) have been identified and dated. The planktonic foraminifers, however, have been subjected to intense dissolution, especially those in the Miocene sediments. Only some of the zonal boundaries (as defined by Blow, 1969 and 1979 and Bolli, 1966) have been precisely located and given magnetostratigraphic ages (see Tauxe et al. and Poore et al., this vol.).

Our results are shown graphically in Figure 1. The zonal boundaries are plotted on the basis of their magnetostratigraphic positions. Two numerical time scales are given; they assume $66.5 \mathrm{~m} . \mathrm{y}$. and $63.5 \mathrm{~m} . \mathrm{y}$. respectively for the beginning of the Cenozoic. Also shown for comparison are the Neogene time scale of Berggren and Van Couvering (1974) and the Paleogene time scale of Hardenbol and Berggren (1978). Those authors based their computations of magnetostratigraphic age on a 65 $\mathrm{m} . \mathrm{y}$. Cenozoic, and if there were discrepancies between the radiometric and magnetostratigraphic dates they 


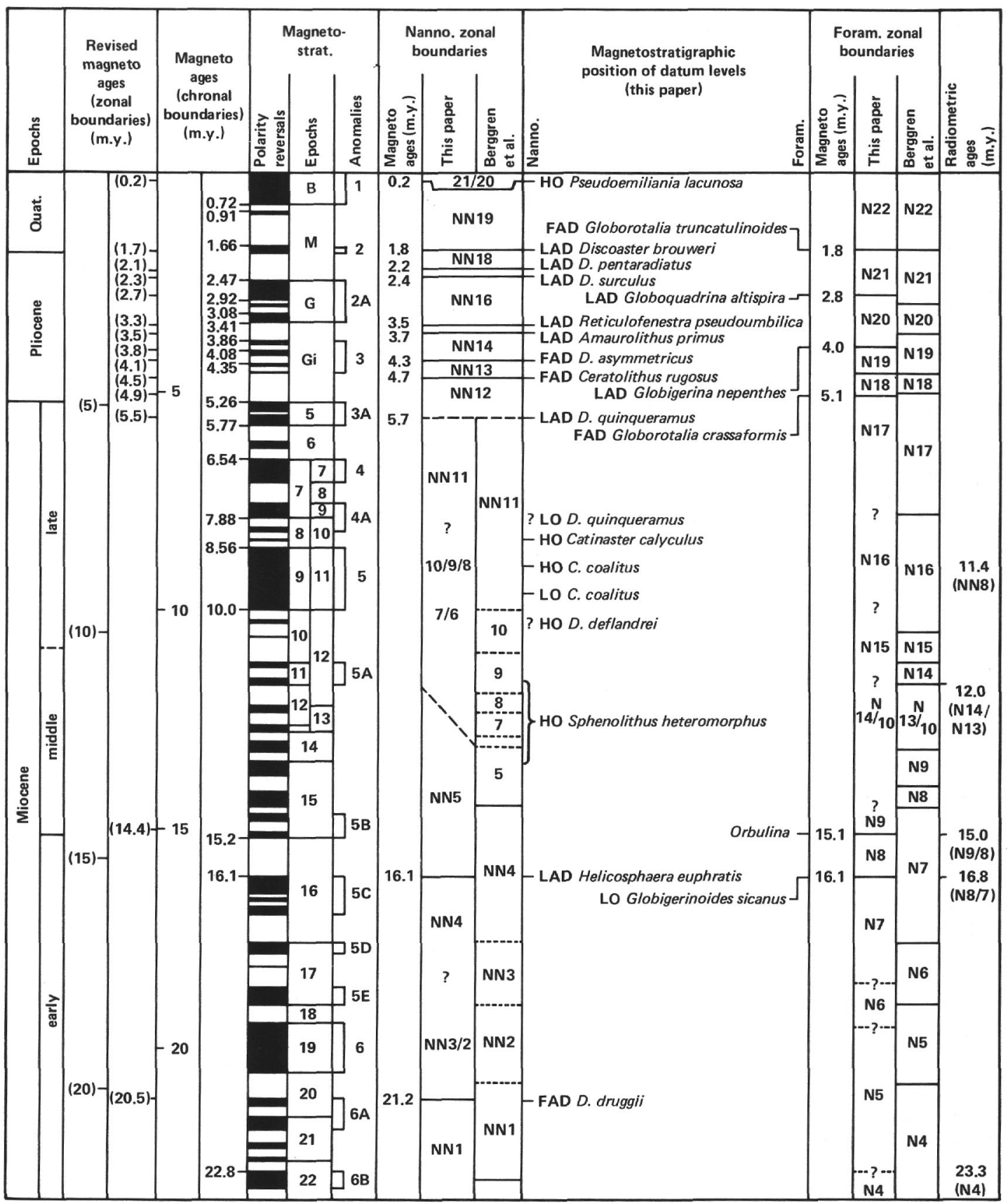

Figure 1. Numerical ages of biostratigraphic zones. The magneto ages are those computed by Tauxe et al. (this vol.) on the basis of a $66.5 \mathrm{~m}$.y. Cenozoic, and the revised magneto ages are those computed for this paper on the basis of a $63.5 \mathrm{~m} . \mathrm{y}$. Cenozoic. The magnetostratigraphy is based upon the correlation of natural remanent magnetization in the sediments with seafloor anomalies; all except Chrons 21 and 22 are recognized in Leg 73 cores. The Neogene epoch terminology is based primarily upon Theyer and Hammond (1974), and the Neogene anomalies are those referred to by Tauxe et al. (this vol.). Two different interpretations of the correlation of magnetostratigraphic epochs and seafloor anomalies are given (see text for detail). The chrons with prefix $\mathrm{C}$ have been newly established by the Leg 73 data. The datum levels are positioned magnetostratigraphically, according to the data available from Leg 73 results. The ticks at those levels point to the nannofossil and foraminiferal zonal boundaries, positioned magnetostratigraphically by our results. The foraminiferal and nannofossil zonal boundaries in the column headed Berggren et al. (which gives Neogene dates from the articles by Berggren and Van Couvering, 1974, and Paleogene dates from the article by Hardenbol and Berggren, 1978) are defined by the same datum levels. However, the levels of their zonal boundaries are not primarily magnetostratigraphic; they were placed at a level in this scale according to their assumed numerical ages. The numerical ages for the zones and the chrons in this table are all magnetostratigraphic except those in the first column (which shows the revised magnetostratigraphic ages of the zonal boundaries) and those in the last (which shows the radiometric ages of biostratigraphically dated strata). Abbreviations of species names used to define foraminiferal zones refer to Globigerina ampliapertura, Pseudohastigerina micra, Cassigerinella chipolensis, Turborotalia cerroazulensis, Globigerinatheka semiinvoluta, Truncorotaloides rohri, and Turborotalia possagnoensis. 


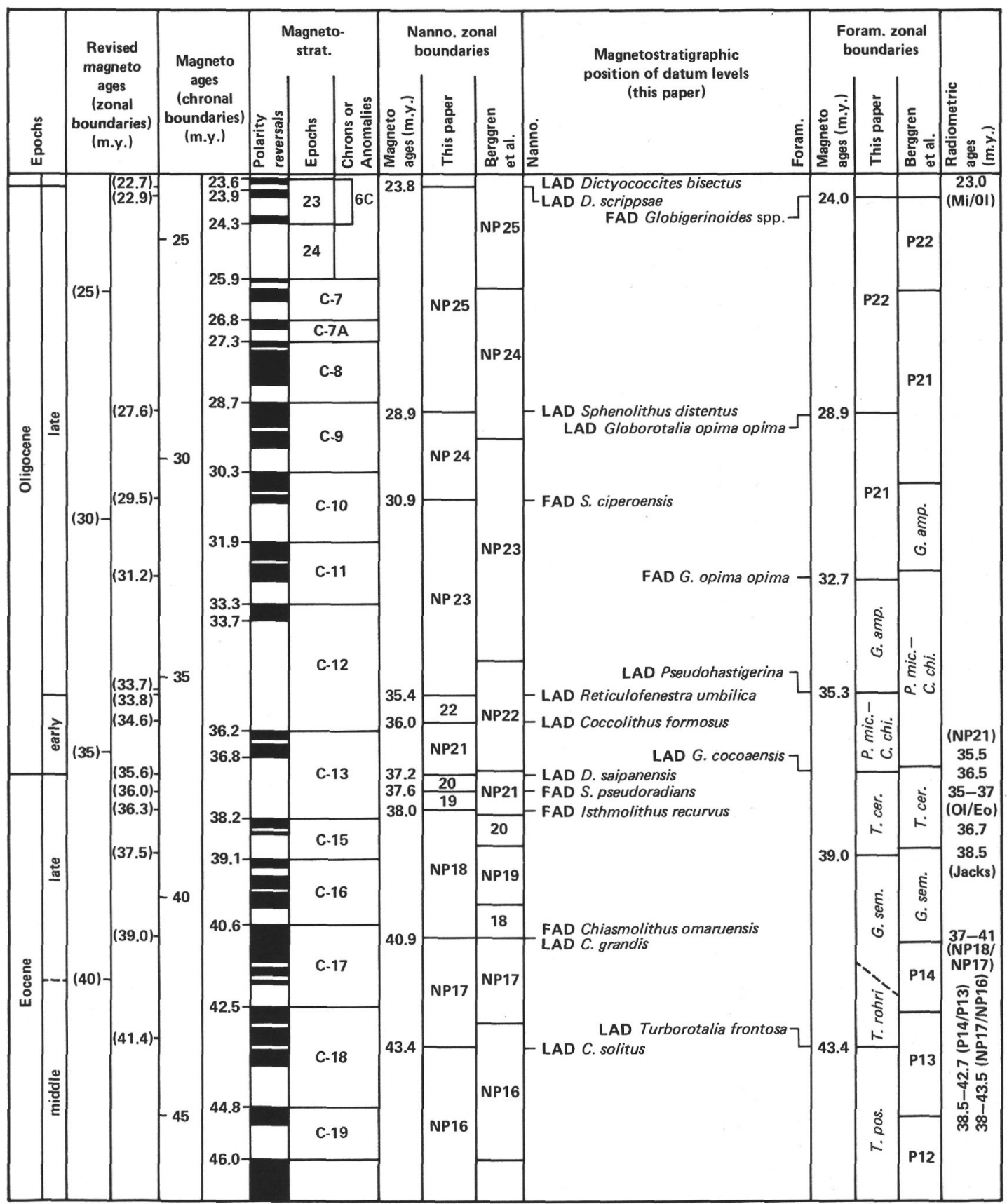

Figure 1. (Continued).

placed greater reliance on the radiometric dates. Zonal boundaries resulting from our studies of the Leg 73 cores are indicated by event markers; the key radiometric dates of fossil zones are cited from Ryan et al. (1974), Hardenbol and Berggren (1978), and Odin (1978). The numerical ages of the zonal boundaries are also given in Tables 1 to 3 .

\section{NUMERICAL AGES OF NEOGENE BOUNDARIES}

\section{Nannofossil Zonal Boundaries}

The age of $0.2(0.2) \mathrm{m} . \mathrm{y}$. for the zonal boundary NN20/NN19 is not as accurate as could be determined from good piston core data, because the topmost subbottom sediments are seldom recovered by DSDP coring. Piston core studies made by Gartner (1973) indicate the age of this boundary, which is defined by the LAD of Pseudoemiliania lacunosa, to be about $0.35 \mathrm{~m} . \mathrm{y}$.

The ages for the top of NN18 (LAD Discoaster brouweri), NN17 (LAD D. pentaradiatus), NN16 (LAD D. surculus), NN15 (LAD Reticulofenestra pseudoumbilica), NN14 (LAD Amaurolithus primus), NN13 (FAD D. asymmetricus), NN12 (FAD Ceratolithus rugosus) are 1.8 (1.74), $2.2(2.1), 2.4(2.3), 3.5(3.3), 3.7$ (3.5), 4.3 (4.1), and 4.7 (4.5) m.y., respectively. The age for the top of NN18 falls within the Olduvai Event and is iden- 


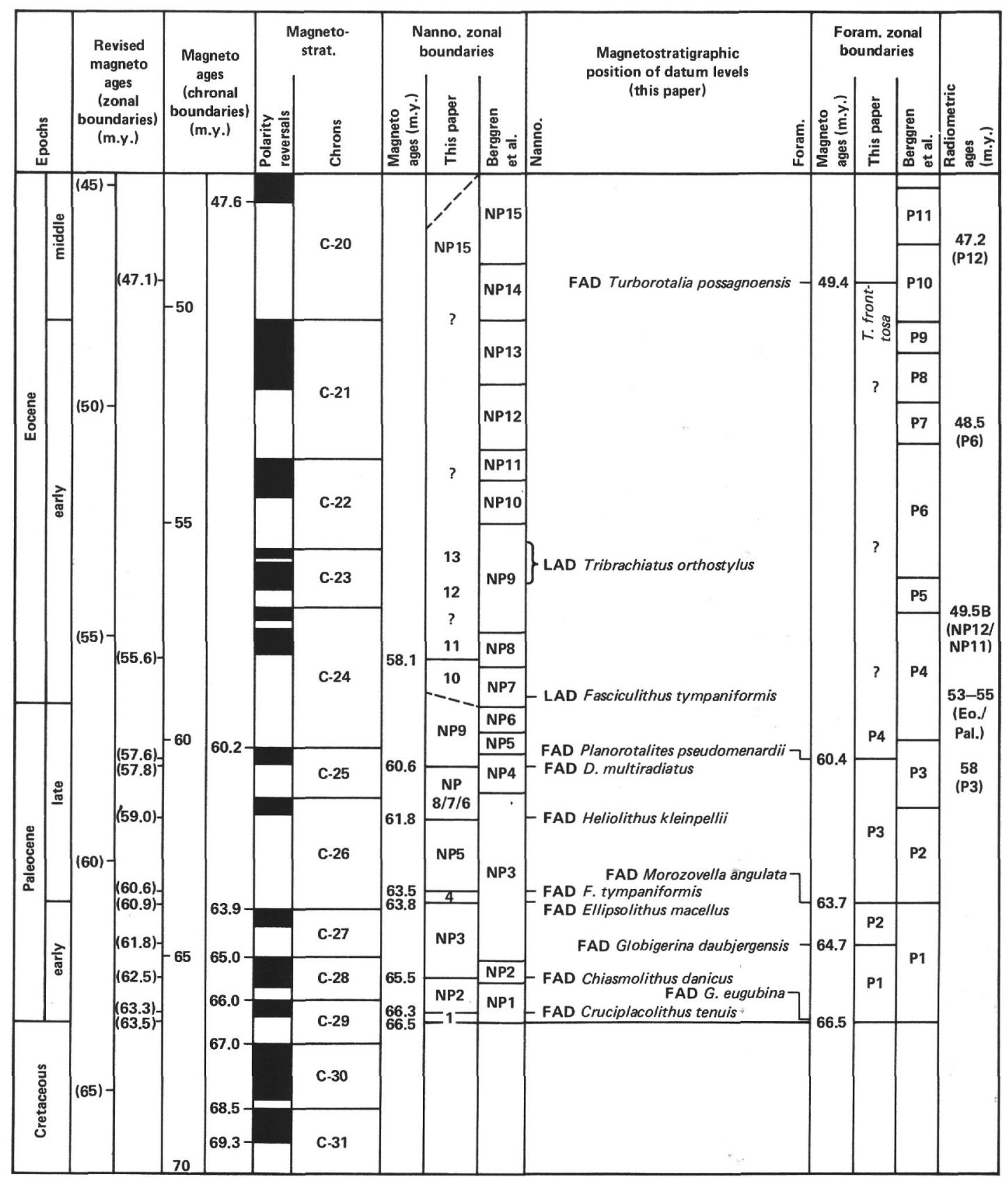

Figure 1. (Continued).

tical to that determined by Gartner (1973). The ages for the tops of NN17 and NN16, which fall within the reversely magnetized interval below the Olduvai, are about the same as, or slightly older than, Gartner's ages for those boundaries.

The top of NN15, defined by the LAD of $R$. pseudoumbilica, lies just below the Gauss/Gilbert boundary; this is lower than the boundary given by Gartner (1973), who placed the datum level within the uppermost normal event in the Gauss Epoch. He did remark that "toward the top of its range this species is rare and represented mostly by relatively small specimens" (p. 2027). Discussions with S. Gartner and N. Shackleton confirmed that those "small specimens" may belong to another taxonomic group, and that the LAD of $R$. pseudo- umbilica as defined by our cores in Holes 519, 521, and 522 should represent a more reliable datum level. If so, the top of NN15 should have an age of 3.5 (3.3) m.y.

The top of NN13 falls within the reversely magnetized interval between the Nunivak and $C_{1}$ event of the Gilbert, and the top of NN12 falls just below the $C_{2}$ event. Both of these marker horizons are magnetostratigraphically lower than those determined by Gartner. The boundaries are defined by the respective FADs of $D$. asymmetricus and $C$. rugosus. Our ranges are probably more reliable, although one cannot rule out an LO extended by downhole contamination, thus giving an apparently earlier FAD. If our calibration is correct, the tops of those two zones have ages of 4.3 (4.1) and 4.7 (4.5) m.y., respectively. 
Table 1. Numerical ages of Neogene nannofossil zonal boundaries (magnetostratigraphy).

\begin{tabular}{|c|c|c|c|c|c|c|c|}
\hline $\begin{array}{c}\text { Datum } \\
\text { (top of zone) }\end{array}$ & Event & Hole & Epoch or chron & $\begin{array}{c}\text { Age } \\
\text { (m.y.) }\end{array}$ & $\begin{array}{l}\text { Alternative } \\
\text { age } \\
\text { (m.y.) }\end{array}$ & $\begin{array}{l}\text { Data } \\
\text { quality }\end{array}$ & $\begin{array}{c}\text { Biostrat. } \\
\text { control }\end{array}$ \\
\hline NN19 & LAD Pseudoemiliania lacunosa & $519,521,522$ & Bruhnes & 0.2 & 0.2 & Fair & V. good \\
\hline NN18 & LAD Discoaster brouweri & 519,521 & Matuyama & 1.8 & 1.74 & V. good & V. good \\
\hline NN17 & LAD D. pentaradiatus & $519,521,522$ & Matuyama & 2.2 & 2.1 & V. good & V. good \\
\hline NN16 & LAD D. surculus & $519,521,522$ & Matuyama & 2.4 & 2.3 & V. good & V. good \\
\hline NN15 & LAD Reticulofenestra pseudoumbilica & $519,521,522$ & Gilbert (top) & 3.5 & 3.3 & V. good & V. good \\
\hline NN14 & LAD Amaurolithus primus & $519,521,522$ & Gilbert & 3.7 & 3.5 & V. good & V. good \\
\hline NN13 & FAD D. asymmetricus & 519 & Gilbert & 4.3 & 4.1 & V. good & V. good \\
\hline NN12 & FAD Ceratolithus rugosus & 519 & Gilbert & 4.7 & 4.5 & Good & Good \\
\hline NN11 & LAD D. quinqueramus & 519 & Epoch 5 & 5.7 & 5.5 & Fair & Poor \\
\hline NN10 & FAD D. quinqueramus & 519,520 & ? & - & - & Poor & Poor \\
\hline NN9 & LAD $D$. hamatus & $521 \mathrm{~A}$ & Chron C-5 (top) & - & - & Poor & Poor \\
\hline NN8 & FAD $D$. hamatus & $521 \mathrm{~A}$ & Chron C-5 & - & - & Poor & Poor \\
\hline NN7 & FAD Catinaster coalitus & $519,521,521 \mathrm{~A}$ & Chron C-5 & 9.6 & 9.2 & Good & Good \\
\hline NN5 & LAD Sphenolithus heteromorphus & $520,521,521 \mathrm{~A}$ & Chron C-5A & 11.7 & 11.2 & Poor & Good \\
\hline NN4 & LAD Helicosphaera euphratis & 521 & Chron C-5C (top) & 16.1 & 15.4 & V. good & Fair \\
\hline NN1 & FAD D. druggii & 522 & Chron C-6A & 21.2 & 20.5 & Good & Good \\
\hline
\end{tabular}

Table 2. Numerical ages of Paleogene nannofossil zonal boundaries (magnetostratigraphy).

\begin{tabular}{|c|c|c|c|c|c|c|c|}
\hline $\begin{array}{c}\text { Datum } \\
\text { (top of zone) }\end{array}$ & Event & Hole & Chron & $\begin{array}{c}\text { Age } \\
(\mathrm{m} . \mathrm{y} .)\end{array}$ & $\begin{array}{l}\text { Alternative } \\
\text { age } \\
\text { (m.y.) }\end{array}$ & $\begin{array}{l}\text { Data } \\
\text { quality }\end{array}$ & $\begin{array}{l}\text { Biostrat. } \\
\text { control }\end{array}$ \\
\hline NP25 & LAD Discoaster bisectus & $522 \mathrm{~A}$ & C-6C-R1 & 23.8 & 22.7 & V. good & V. good \\
\hline NP24 & LAD Sphenolithus distentus & 522 & C-9-N (top) & 28.9 & 27.6 & V. good & V. good \\
\hline NP23 & FAD S. ciperoensis & 522 & C-10-N2 (bottom) & 30.9 & 29.5 & V. good & V. good \\
\hline NP22 & LAD Reticulofenestra umbilica & 522 & $C-12-R$ & 35.4 & 33.8 & V. good & V. good \\
\hline NP21 & LAD Coccolithus formosus & 522 & $\mathrm{C}-12$ & 36.0 & 34.6 & V. good & V. good \\
\hline NP20 & LAD D. saipanensis & 522 & $C-13-R$ & 37.2 & 35.6 & V. good & V. good \\
\hline NP19 & FAD $S$. pseudoradians & 523 & $C-13-R$ & 37.6 & 36.0 & Fair & Fair \\
\hline NP18 & FAD Isthmolithus recurvus & 523 & C-13-R & 38.0 & 36.3 & Fair & Fair \\
\hline NP17 & LAD Chiasmolithus grandis & 523 & $\mathrm{C}-17-\mathrm{N} 1$ & 40.9 & 39.0 & V. good & Good \\
\hline NP16 & LAD C. solitus & 523 & C-18-R2 & 43.4 & 41.5 & V. good & V. good \\
\hline NP15 & $\begin{array}{l}\text { Betw. LAD Nannotetrina fulgens } \\
\text { and LAD C. gigas }\end{array}$ & 523 & $\mathrm{C}-20$ & $46.7-48.2$ & $44.5-46.0$ & V. good & Fair \\
\hline NP12 & LAD Tribrachiatus orthostylus & 524 & $\mathrm{C}-23-\mathrm{N}$ & $55.6-56.5$ & $53.1-54.0$ & Poor & Fair \\
\hline NP11 & FAD D. lodoensis & 524 & C-24-N & $57-57.5$ & $54.5-55$ & Poor & Fair \\
\hline NP10 & FAD $T$. orthostylus & 524 & $C-24-R$ & 58.1 & 55.6 & Fair & Fair \\
\hline NP9 & LAD Fasciculithus tympaniformis & 524 & C-24-R & $59.0 \pm 0.2$ & $56.4 \pm 0.2$ & Fair & Good \\
\hline NP8 & FAD D. multiradiatus & 524 & $\mathrm{C}-25-\mathrm{N} / \mathrm{C}-25-\mathrm{R}$ & 60.6 & 57.8 & Fair & V. good \\
\hline NPS & FAD Heliolithus kleinpellii & 524 & $C-26-R$ & 61.8 & 59.0 & Fair & V. good \\
\hline NP4 & FAD $F$, tympaniformis & 524 & $C-26-R$ & 63.3 & 60.6 & Good & V. good \\
\hline NP3 & FAD Ellipsolithus macellus & 524 & $C-26-R$ & 63.8 & 60.9 & V. good & V. good \\
\hline NP2 & FAD C. danicus & 524 & C-28-N & 65.5 & 62.5 & V. good & V. good \\
\hline NP1 & FAD C. tenuis & 524 & C-29-N & 66.3 & 63.3 & V. good & V. good \\
\hline
\end{tabular}

Table 3. Numerical ages of foraminiferal datum levels (magnetostratigraphy).

\begin{tabular}{|c|c|c|c|c|c|c|}
\hline Event & Hole & Epoch or Chron & $\begin{array}{l}\text { Age } \\
\text { (m.y.) }\end{array}$ & $\begin{array}{c}\text { Alternative } \\
\text { age } \\
\text { (m.y.) }\end{array}$ & $\begin{array}{l}\text { Data } \\
\text { quality }\end{array}$ & $\begin{array}{c}\text { Precision, } \\
\text { biostrat. } \\
\text { control }\end{array}$ \\
\hline $\begin{array}{l}\text { FAD Globorotalia truncatulinoides } \\
\text { (top Pliocene) }\end{array}$ & 522 & Matuyama & 1.8 & 1.7 & V. good & Good \\
\hline FAD Globoquadrina altispira & 519 & Gauss & 2.8 & 2.7 & V. good & Good \\
\hline LAD Globigerina nepenthes & 519 & Gilbert & 4.0 & 3.8 & V. good & Good \\
\hline $\begin{array}{l}\text { FAD Globorotalia crassaformis } \\
\text { ( top Miocene) }\end{array}$ & 519 & Gilbert & 5.1 & 4.9 & Good & Good \\
\hline FAD G. cibaoensis & 519 & Gilbert (bottom) & 5.2 & 5.0 & Good & Fair \\
\hline FAD Orbulina spp. & 521 & C-5B & 15.1 & 14.4 & V. g & V. good \\
\hline FAD G. sicanus & 521 & C-5B (bottom) & 16.1 & 15.4 & V. good & Fair \\
\hline $\begin{array}{l}\text { FAD Globigerinoides spp. } \\
\text { (top Oligocene) }\end{array}$ & 522 & $\mathrm{C}-6 \mathrm{C}-\mathrm{N} 1$ & 24.0 & 22.9 & V. good & V. good \\
\hline LAD Globorotalia opima opima & 522 & C-9- & 28. & 27.6 & V. good & Good \\
\hline FAD G. opima opima & 522 & $\mathrm{C}-11-\mathrm{N} 2$ & 32. & 31.2 & V. $\mathrm{g}$ & Fair \\
\hline LAD Pseudohastigerina spp. & 522 & C-12-R & 35.3 & 33.7 & V. good & Good \\
\hline $\begin{array}{l}\text { LAD Turborotalia cerroazulensis } \\
\text { (top Eocene) }\end{array}$ & 522 & C-13-R & 37.1 & 35.5 & V. good & Good \\
\hline $\begin{array}{l}\text { LAD Globigerinatheka sp. af. } \\
\text { G. semiinvoluta }\end{array}$ & 523 & $\mathrm{C}-16-\mathrm{N}$ & 39.0 & 37.5 & V. good & Fair \\
\hline LAD Acarinina spp. & 523 & C-17 & 42 & 40 & V. good & Fair \\
\hline LAD T. frontosa & 523 & C-18-R2 & 43.4 & 41.4 & & V. good \\
\hline FAD $T$. possagnoensis & 523 & $C-20-R$ & 49.4 & 47.1 & Good & Good \\
\hline FAD Planorotalites pseudomenardii & 524 & $\mathrm{C}-25-\mathrm{N}$ & 60.4 & 57.6 & Fair & Good \\
\hline FAD Morozovella angulata & 524 & C-26-R & 63.7 & 60.8 & V. go & V. good \\
\hline a daubjergensis & 524 & $C-27-R$ & 64.7 & 61.8 & V. good & V. good \\
\hline FAD G. eugubina & 524 & C-29-R & 66.4 & 63.4 & V. good & V. good \\
\hline
\end{tabular}

The top of NN11 is defined by the LAD of $D$. quinqueramus and seems to fall within the lower normally magnetized interval of Epoch 5 (Chron C-3A), giving it an age of 5.7 (5.5) m.y. However, fossils of this species are only abundant in the sediments of Hole 520, where the magnetostratigraphy has not been worked out, and they are very rare and poorly preserved in the sediments of Holes 519 and 521, where the magnetostratigraphy for this interval is fair or poor. Gartner placed this datum level within the middle reversely magnetized inter- 
val of Epoch 5, which should have an age of 5.6 (5.4) m.y., according to our magnetostratigraphy.

The top of NN10, which is defined by the FAD of $D$. quinqueramus, cannot be determined precisely in our sections because the species occurs rarely and its lower range has probably been truncated by dissolution.

Determining the age of the nannofossil zones NN9 to NN6 (middle Miocene, Serravalian Stage) presents a problem. Current interpretations have relied mainly upon the radiometric ages of two ash beds in the Experimental Mohole by Dymond (1966), namely $11.4 \pm 0.6$ m.y. for NN8 and 12.3 \pm 0.4 m.y. for NN6 (see Ryan et al., 1974). A secondary indicator is a correlation of the nannofossil zone NN8 to the foraminifer zone N13, which in turn has been correlated to a radiometrically dated Hipparion datum of 12.4 m.y. (see Berggren and Van Couvering, 1974). A tertiary indicator is a correlation of NN8 to a radiolarian zone Cannartus pattersoni, which is placed in Epoch 11; this epoch has a magnetostratigraphic age of $11.5 \mathrm{~m}$.y. on the basis of its correlation to Seafloor Anomaly 5A (see Theyer and Hammond, 1974).

We found, however, the FADs and LADs of several key nannofossil species at levels that were significantly higher than suggested by previous authors.

The top and base of NN9 have not been determined unequivocally, because only one occurrence of $D$. hamatus, the marker species for this zone, was noted (see von Salis, this vol.). The species was found in Hole 521A at $48.45 \mathrm{~m}$ sub-bottom, near the top of Chron C$5-\mathrm{N}$. We would disregard this very flimsy bit of evidence except for the unusually high (recent) levels of occurrence of Catinaster coalitus. This nannoplankton species has its last appearance in the upper part of NN9 and its first appearance at the base of NN8 (which is equivalent to the top of NN7). All our data, which are from three holes $(519,521$, and 521A) and result from independent investigations by a shipboard team (Percival, Tauxe, and others) and a shore-based team (von Salis, Heller, and others), indicate that the LAD and FAD of the species are in Chron C-5-N instead of Chron C-5A, as previously suggested. The magnetostratigraphic age of NN8 is thus 9 to 10 m.y., not 11 to 12 m.y., as determined by radiometric dating.

Our magnetostratigraphic data reopened an old controversy concerning the correlation between the magnetostratigraphic epochs in Pacific piston cores and seafloor anomalies. The nannofossil zone NN8 in the Mohole has been biostratigraphically correlated with a radiolarian fauna in the piston cores that correlates to the magnetostratigraphic Epoch 11 of Theyer and Hammond (1974). Epoch 11 was originally correlated to Seafloor Anomaly 5, or Chron C-5-N (Foster and Opdyke, 1970). Such an interpretation would be in agreement with our data. However, Dreyfus and Ryan (1972; unpublished, cited in Ryan et al., 1974) have proposed a correlation between Epoch 11 and Seafloor Anomaly $5 \mathrm{~A}$, or Chron C-5A. Their correlation was developed to reconcile magnetostratigraphic and radiometric dating, but it is now contradicted by our results.
A lack of correlation between radiometrically dated middle Miocene nannofossil zones and magnetostratigraphy was also noted at Site 396 in the North Atlantic. At that site NN6 sediments with an estimated biostratigraphic age of $13.6 \pm 1.6 \mathrm{~m}$.y. (Bukry, 1979) lie on top of an Anomaly 5 crust with an extrapolated magnetostratigraphic age of 8.8 m.y. (Purdy et al., 1979)!

The correlation between middle Miocene nannofossil and foraminifer zones still needs to be clarified. The available data, however, suggest the placement of NN8 in magnetostratigraphic Chron $\mathrm{C}-5-\mathrm{N}$ regardless of the consequences for the nannofossil-foraminifer correlation. In the Pacific, the nannofossil zone NN8 has been correlated to the foraminifer zones N13 and N14; this correlation is not well established in the Atlantic. At Site 360 (Cape Basin), the key interval has not been thoroughly investigated, and at Sites 357 (Rio Grande Rise) and 362 (Walvis Ridge) the sediments containing NN8 fossils yield a microfauna younger than N14 (see the biostratigraphic chapters in Supko, Perch-Nielsen, et al., 1977, and Jenkins, 1978). Even if we accept the Pacific correlation, we might still place NN8 in Chron 5-N, because Globigerina ruber, which made a last appearance toward the end of N13 time (before it reappeared in the early Pliocene) was found in the bottommost core of Hole 16 drilled on an Anomaly 5 crust (Maxwell, Von Herzen, et al., 1970, p. 183), suggesting a Chron C-5-N age for N13. Information from another site fails to corroborate an NN8-N13 correlation, however. In Hole 366A, which was drilled in the equatorial Atlantic, the sediments containing nannofossils of Zone NN10 (C. calyculus: Core 13A) yield a foraminiferal fauna of Zone N17 (Globorotalia plesiotumida), and the sediments containing Zone NN8 nannofossils (C. coalitus; Core 14A) yield a microfauna of Zone N16 (G. acostaensis). Further, sediments containing nannofossils of Zones NN7 and NN6 (D. exilis s.i.; Cores $15 \mathrm{~A}$ and $16 \mathrm{~A}$ ) yield a microfauna belonging approximately to Zones $\mathrm{N} 10$ to $\mathrm{N} 12$ (G. fohsi lobata, G. fohsi fohsi, and G. peripheroacuta). This correlation of nannofossil and foraminiferal zones is similar to that we found in the Site 519 and 521 cores (see the site chapters). The correlation of the foraminifer zone N16 to magnetostratigraphic Chron C-5-N ("long normal epoch") is fairly certain (Berggren and Van Couvering, 1974), and on the basis of an NN8-N16 correlation the placement of NN8 in Chron C-5-N would thus also be justified.

A separate argument for an older date for NN8 has been based upon a correlation of this nannofossil zone with the foraminifer zone $\mathrm{N} 13$ and hence to the 12.5 m.y. Hipparion datum. However, the Hipparion datum has recently been dated magnetostratigraphically to fall within Chron C-5-N in Pakistan (Opdyke et al., 1979; Tauxe, 1979). If this evidence is valid, an NN8-Hipparion correlation would also place the nannofossil zone in Chron C-5-N.

In summary, the evidence clearly indicates a Chron C-5-N magnetostratigraphic age for the base of NN8, giving it a numerical age of $9.6(9.2) \mathrm{m} . \mathrm{y}$. , if the seafloor spreading rate has been linear. In other words, we have 
to conclude either that the radiometric dates by Dymond for NN8 and NN6 are too old or that the seafloor spreading rate was significantly different from linear during the middle Miocene, as Hsü and Andrews first suggested (in Maxwell, Von Herzen, and Shipboard Scientific Party, 1970, pp. 445-453) to explain the lithofacies changes of this age. The first alternative is not only more plausible but is also supported by the presently available evidence.

The top of NN5 is defined by the LAD of Sphenolithus heteromorphus. Berggren and Van Couvering (1974, p. 11) mentioned that the disappearance horizon may have been slightly diachronous. Shore-based studies of Hole 521A cores suggest that the top of NN5 may be as high as a normally magnetized interval of Chron C-5-A (Epoch 11 of Dreyfus and Ryan) and have a magnetostratigraphic age of 11.2 to 11.7 m.y., more than 1 m.y. younger than that previously suggested.

The top of the nannofossil zone NN4 is approximated by the FAD of Helicosphaera euphratis. This level corresponds to the boundary between magnetostratigraphic Chrons C-5B and C-5C (within Epoch 16) and should have an age of $16.1(15.4) \mathrm{m} . \mathrm{y}$. This nannofossil zonal boundary has also been correlated to the FAD of the foraminifer $G$. sicanus, which has a radiometric age of $16.8 \pm 0.5 \mathrm{~m} . \mathrm{y}$. in New Zealand (see Ryan et al., 1974 , p. 671). The agreement with the currently accepted Neogene geochronology is thus again reasonably good.

The tops of the nannofossil zones NN3 and NN2 are not defined in this study because the marker species have not been found. However, the top of NN1, which has been defined by the FAD of $D$. druggii, was found just below the top of Chron C-6A-N1 (the middle of Epoch 20 of Theyer and Hammond, 1974). The calibrated age is $21.2(20.5) \mathrm{m}$.y. The nannofossil-foraminifer correlation suggests that the top of NN1 is slightly ( $1 \mathrm{~m} . \mathrm{y}$.) younger than the top of the foraminifer zone N4 and still younger than the $23.3 \mathrm{~m}$.y. old volcanic ash interbedded in the N4 sediments of Italy (Ryan et al., 1974). Our magnetostratigraphic age for the nannofossil datum does not conflict with the radiometric dating.

\section{Foraminiferal Zonal Boundaries}

The Neogene foraminiferal assemblages from the middle-latitude South Atlantic sites are low in species diversity (Saito in Maxwell, Von Herzen, et al., 1970 and Jenkins, 1978). The task of zonation is further hindered by the intensive dissolution of planktonic foraminifers. Many of the zonal markers are absent. Therefore, we did not invest too much time or effort in determining the Neogene foraminiferal zones. We did however make use of our excellent magnetostratigraphy to check the chronology of several important datum levels.

The Pliocene-Quaternary datum levels, such as the LOs of Globorotalia truncatulinoides and the HOs of Globoquadrina altispira and Globigerina nepenthes, have about the same magnetostratigraphic position as, or differ only slightly from, the FADs or LADs of those species given by Berggren and Van Couvering (1974). The Globorotalia truncatulinoides datum lies, as usual, within the Olduvai interval in Hole 522. The Globoquadrina altispira datum lies above the Kaena Event of the Gauss Epoch, indicating a slightly younger FAD than formerly supposed. The Globigerina nepenthes datum lies within the Cochiti Event, as established previously (Berggren and Van Couvering, 1974, p. 30). Both Pliocene event markers occur at higher magnetostratigraphic levels at Site 519 than at Pacific Site RC 12-66, where the piston cores were recovered that were studied by Saito et al. (1975, p. 229).

The FAD of Globorotalia crassaformis is significantly older at Site 519 than the FAD of this species in the Pacific. Kennett and Watkins (1972) showed that $G$. crassaformis first appeared at or close to the top of the Nunivak Event at 3.97 m.y. Our data showed, however, an FAD of the species in the reversely magnetized interval below the $\mathrm{C}_{2}$ Event, at about 5.1 (4.9) m.y.

The HOs of G. margaritae and of Globoquadrina dehiscens may be slightly or significantly older than their LADs in the Pacific (Poore et al., this vol.). However, our ranges for those species may have been truncated slightly by the Miocene-Pliocene dissolution.

We have not been able to calibrate the middle Miocene foraminiferal zones magnetostratigraphically because of the poor preservation of the microfauna and some uncertainties in the magnetostratigraphic interpretation. During our previous discussion, we did point out the possibility that the Globigerina ruber (extinction) datum, as well as the Globorotalia mayeri (extinction) datum, may be younger than the beginning of Chron C-5-N. If so, the ages of the zonal boundaries of N15/N14 and of N14/N13 may be significantly younger than the currently accepted values.

The LOs of G. cibaoensis and Globigerinoides conglobatus are just above and just below the Gilbert Epoch 5 boundary, respectively. Bolli (pers. comm., 1982) placed the FAD of $G$. conglobatus at the Pliocene/Miocene boundary, but both species occur in the late Miocene sediments of the Leg 21 sites (Kennett, 1973, pp. 578 and 582). If the LOs of Globorotalia cibaoensis at Site 519 represent FADs in the late Miocene, our data would suggest that the Pliocene/Miocene boundary might be placed near the base of the Gilbert Epoch. However, the LOs of both species at our sites may occur at levels higher than their FADs.

The FAD of Globigerina nepenthes is an important event marker in current time scales. The marker defines the foraminifer zonal boundary N14/N13, and it has an estimated age of $12.0 \mathrm{~m}$.y. because it is slightly higher than the radiometrically dated Hipparion datum of 12.5 m.y. (Berggren and Van Couvering, 1974). We have found, however, the lowest occurrence of a Globigerina sp. aff. G. nepenthes, together with the LO of Sphaeroidinellopsis subdehiscens (the marker for the N13/N12 boundary) and the LO of $G$. druryi (FAD in N11) to lie at a level (in Chron C-5C) below the Orbulina datum (the marker for the N9/N8 boundary). Those lowest occurrences are very odd indeed, and they seem to suggest that the $G$. nepenthes datum is not a reliable event marker in the South Atlantic.

The Orbulina (initial appearance) datum at the top of Chron C-5C (Epoch 16) is very accurately determined at Site 521. The 15.1 (14.4) m.y. magnetostratigraphic age 
is in agreement with the estimated radiometric age of 15 m.y. for this datum (Ikebe et al., 1972; McDougall and Page, 1975). We consider this datum to be a well established event marker.

The N8/N7 zonal boundary has been tentatively defined by the LO of Globigerinoides sicanus; the species first appears at the base of N8 in the Cape Bojador Hole 397 (Salvatorini and Cita, 1979, p. 328). The 16.1 (15.4) m.y. magnetostratigraphic age of the LO of $G$. sicanus in Hole 521 lies within the error limits of the $16.8 \pm 0.5$ m.y. radiometric age for the $\mathrm{N} 8 / \mathrm{N} 7$ boundary cited by Ryan et al. (1974, p. 671).

\section{NUMERICAL AGES OF PALEOGENE BOUNDARIES}

\section{Nannofossil Zonal Boundaries}

The top of NP25 marks the Miocene/Oligocene boundary. The level has been best determined in Hole $522 \mathrm{~A}$, by the LADs of secondary indicators Dictyococcites scrippsae and $D$. bisectus, at a level just below the boundary between Chron C-6C-N1 and Chron C-6C-R1 (see Percival, this vol. and the Site 522 chapter). The magnetostratigraphic age should thus be 23.8 (22.7) m.y., and this age agrees remarkably well with the 23 m.y. radiometric age for this boundary estimated by Odin (1978) and Curry and Odin (1982).

The top of NP24, which is defined by the LAD of Sphenolithus distentus, falls just below the top of Chron C-9-N; it has a magnetostratigraphic age of $\mathbf{2 8 . 9}$ (27.6) m.y.

The top of NP23, which is defined by the FAD of $S$. ciperoensis, is about $0.1 \mathrm{~m}$.y. younger than the boundary of Chrons C-10-N2 and C-10-R2. It has a magnetostratigraphic age of 30.9 (29.5) m.y. Lowrie et al. (1982, p. 423) found the lowest occurrence of $S$. ciperoensis within the interval of Chron C-9-N at Gubbio; the apparently late first appearance there is probably the result of dissolution and produces a paradoxical situation in which the top of their NP23 lies above (not below) NP24.

The top of NP22, defined by the LAD of Reticulofenestra umbilica, and the top of NP21, defined by the LAD of Coccolithus formosus, both fall within the long reversely magnetized interval Chron C-12-R. The boundaries have magnetostratigraphic ages of 35.4 (33.8) m.y. and 36.0 (34.6) m.y., respectively.

Radiometric ages from glauconites in the Paleogene sediments of southwest Germany are available for comparison (Gramann et al., 1975). The potassium/argon $(\mathrm{K} / \mathrm{Ar})$ age is $36.6 \pm 0.7 \mathrm{~m}$.y. for the glauconite near the base of NP21 sediments at Helmstadt, and it is $35.5 \pm$ $0.7 \mathrm{~m}$.y. for the glauconite in unfossiliferous sand below the top of NP21 at Lehrte. These dates suggest that the top of NP21 should be slightly younger than $35.5 \pm 0.7$ m.y., in general agreement with our magnetostratigraphic interpretation.

The top of NP20 is defined by the LAD of Discoaster saipanensis and falls within the interval Chron C-13-R, with a magnetostratigraphic age of 37.2 (35.6) m.y. This datum level is commonly considered the Oligocene/Eocene boundary of the nannofossil zonation.

Ages for the top of NP19 and the top of NP18 have not been accurately determined because of the poor recovery of Core 29 at Site 523. The lowest occurrence of S. pseudoradians occurs in Core 523-28,CC. The lowest occurrence of Isthmolithus recurvus is found in a tiny speck of nannofossil ooze that represents all we recovered from the 4-m interval of Core 29. Apparently the FADs of both species should be in that missing interval, which includes the lower two-thirds of Chron C-13-R. If the FAD of $S$. pseudoradians is placed near the top and the FAD of $I$. recurvus is placed near the bottom of the interval, we obtain estimated magnetostratigraphic ages of $37.6(36.0) \mathrm{m} . \mathrm{y}$. and $38.0(36.3) \mathrm{m} . \mathrm{y}$. for those datum levels.

Microtektites have been found in the uppermost Eocene sediments belonging to NP20 and NP19 at Site 94, sediments belonging to NP20, NP19, and NP18 (the $D$. barbadiensis zone of Gartner, 1973) at Holes 161A, 167, 216, and 296 (Glass and Crosbie, 1982), and in sediments belonging to NP20 in Barbados (Perch-Nielsen, pers. comm., 1982). The microtektites from a correlative horizon in Piston Core RC 9-58 have been dated at 34.6 \pm 4.2 m.y. by the fission-track method (Glass and Crosbie, 1982). The presumably synchronous North American textites are more precisely dated to have an age of about 34 or $35 \mathrm{~m} . y$. The radiometric ages are thus significantly younger than our magnetostratigraphic age for the top of NP19, even if we adopt the minimum (alternate) age of $36.0 \mathrm{~m} . \mathrm{y}$.

The top of NP17, which is defined by the LAD of the secondary indicator Chiasmolithus grandis, falls within Chron C-17-N1 and has an estimated age of 40.9 (39.0) m.y.

Odin and Curry (1981) gave an extrapolated radiometric date of $37 \pm 1.5 \mathrm{~m}$.y. as the age of the top of NP17. The extrapolation is based upon Odin's (1975) $\mathrm{K} / \mathrm{Ar}$ age of 38.5 to $40 \mathrm{~m} . \mathrm{y}$. for glauconite near the base of the Barton Beds in the London Basin. Pomerol (1978) cited a 38 m.y. K/Ar date given by Elewaut and others for the Barton Beds; Pomerol thought that the Bartonian (sensu lato) age corresponds to six nannofossil zones (NP21 to NP16), although W. Berggren suggests that it correlates only to Zones NP17 and NP16 (pers. comm., 1982). At any rate, Odin's extrapolated ages are too young.

The top of NP16 is defined by the LAD of $C$. solitus within Chron C-18-R2, and it should have an age of 43.4 (41.5) m.y. Pomerol (1978) reported that Elewaut and others obtained K/Ar ages of 38.1 to $40.1 \mathrm{~m} . \mathrm{y}$. and $\mathrm{Sr} / \mathrm{Rb}$ ages of 39.5 to $43.5 \mathrm{~m}$.y. for the Asse Clay (early Bartonian of Belgium). Curry and Odin (1982, p. 616) noted that the radiometric dating of this nannofossilbearing formation should provide an estimate of the age of NP16. Our magnetostratigraphic estimates could be reconciled with the $\mathrm{Sr} / \mathrm{Rb}$ ages but seem too old to be reconciled with the $\mathrm{K} / \mathrm{Ar}$ age of this datum level (the date preferred by Odin, 1981, and Curry and Odin, 1982). 
The top of NP15 has not been defined because the marker species, Rhabdosphaera gladius, is missing. The LAD for Nannotetrina fulgens lies within Chron C-20$\mathrm{N} 1$, and the LAD for C. gigas lies within Chron C-20R1. The zonal boundary NP16/NP15 should lie between these two datums, which have magnetostratigraphic ages of 46.7 (44.5) m.y. and 48.2 (46.0) m.y., respectively.

The top of NP14, which is defined on the basis of the FAD of $N$. fulgens, has not been calibrated magnetostratigraphically, because no sediment of this age has been cored. Hardenbol and Berggren (1978) estimated that the top should lie within the lower half of Chron C-20-R. We penetrated sediments of earliest Chron C-20$\mathrm{R}$ age in Hole 523 but failed to recognize this datum.

The top of NP13, which is defined by the FAD of $D$. sublodoensis, is also not recognized in the sediments cored during Leg 73 drilling.

The top of NP12 has been defined by the LAD of Tribrachiatus orthostylus. The datum seems to fall within an interval that has been correlated to Chron C-23-N (see Site 524 chapter). The magnetostratigraphy of this condensed interval is very uncertain, however.

The top of NP11, which is defined by the FAD of $D$. lodoensis, falls within an interval that is correlated with a normally magnetized interval of Chron C-24 and should be about $57.5(55) \mathrm{m} . \mathrm{y}$. in age. The top of NP10, which is defined in Hole 524 by a secondary indicator (the FAD of $T$. orthostylus), has been fairly well correlated to a magnetostratigraphic level near the top of Chron C-24-R2, with a magnetostratigraphic age of 58.1 (55.6) m.y.

Sediments belonging to the nannofossil zones NP12 and NP11 are present in the type Ypresian area of Belgium (Martini, 1971). Curry and Odin (1982) gave 49 m.y. and 51 m.y. as the extrapolated ages for the zonal boundaries NP12/NP11 and NP11/NP10, based upon glauconite dates from the type Ypresian. Hardenbol and Berggren (1978) assigned ages of $52 \mathrm{~m} . \mathrm{y}$. and $53 \mathrm{~m} . \mathrm{y}$. ages to those datum levels, but their numerical ages are contradicted by their own magnetostratigraphic evidence. For example, they noted that the sediment of NP12 age overlies Anomaly 24 crust at DSDP Site 39, so that the minimum magnetostratigraphic age of the NP12/11 boundary should be equivalent to the magnetostratigraphic age of Chron C-24, or $57(54.5)$ to $58(55.5)$ m.y., similar to our finding at Site 524. Also the magnetostratigraphy of the nannofossil datum levels that define the tops of NP11 and NP10 at Gubbio is about the same as that determined by us at Site 524 .

The top of NP9, which is defined by a secondary indicator (the LAD of Fasciculithus tympaniformis), should lie within an uncored interval within Chron C-24-R and have a magnetostratigraphic age of 59.0 (56.4) \pm 0.2 m.y. According to Hardenbol and Berggren (1978), this datum marks the Eocene/Paleocene boundary. Oddly enough, the revised magnetostratigraphic age of 56.4 m.y. is only slightly older than the old radiometric age of $55 \mathrm{~m}$.y. for this boundary. However, Curry and Odin (1982, p. 623) would like to assign a younger age of 53 m.y. Their arguments are as follows:

"The figure of 55 [m.y.] ... proposed in 1964 for the base of the Eocene was based on four determinations.
The first was on the Bashi marls, which subsequently yielded a younger age; the second on a glaucon from Austria, dated rather imprecisely as Early Eocene. The other two were from units dated as Late Paleocene (NP 8 )... [one] subsequently redated in the same laboratory as $6 \%$ younger, and finally a poorly-evolved $(5.3 \% \mathrm{~K})$ glaucony from the Lodo fm., California."

The top of NP8, which is defined by the FAD of $D$. multiradiatus, coincides more or less with the boundary between Chrons C-25-N and C-25-R and has a magnetostratigraphic age of 60.6 (57.8) m.y., a few million years older than the estimate by Odin (1982) on the basis of his dating of nannofossil-bearing sediments of this age.

The top of NP7 and that of NP6 have not been accurately determined because the marker species are absent, but the datum levels should fall within an interval of poor core recovery that can be correlated with Chron C-26-N. Such a magnetostratigraphic interpretation is in line with the fact that NP7 sediment overlies Anomaly 26 crust at DSDP Site 213 (Hardenbol and Berggren, 1978, p. 223).

The top of NP5 (the FAD of Heliolithus kleinpellii), of NP4 (the FAD of F. tympaniformis), and of NP3 (the FAD of Ellipsolithus macellus) all fall within the long, reversely magnetized interval of Chron C-26-R. Their magnetostratigraphic ages are 61.8 (59.0) m.y., 63.3 (60.6) m.y., and 63.8 (60.9) m.y., respectively. The top of NP2 (FAD C. danicus) in Chron C-28-N and the top of NP1 (FAD Cruciplacolithus tenuis) in Chron C-29-N should have magnetostratigraphic ages of $65.5(62.5)$ m.y. and 66.3 (63.3) m.y., respectively.

\section{Foraminiferal Zonal Boundaries}

The microfauna of the Paleogene sediments at Leg 73 sites is fairly well preserved. Most of the Paleogene foraminiferal zones defined by Bolli (1966), Blow (1969), and Stainforth et al. (1975) have been recognized. The correlation of the zonal boundaries to the magnetostratigraphy has been reported in the Site 522, 523, and 524 chapters and in the article by Poore et al. (this vol.). The foraminiferal zonal boundaries are less precisely determined than the nannofossil boundaries because of the less dense spacing of the microfauna samples. The correlation of the nannofossil and foraminiferal zones is with rare exceptions in general agreement with that proposed by Hardenbol and Berggren (1978), but our magnetostratigraphic ages are on the whole older than the numerical ages of those authors, who relied heavily on radiometric dates.

The Miocene/Oligocene boundary in foraminiferal zonation is placed at the top of the Globigerina ciperoensis zone of Bolli (Blow's P22). This datum level is defined at Site 522 by the FAD of Globigerinoides spp. at a level within Chron C-6C-N2, slightly below the top of NP25, which marks the epoch boundary according to nannofossil stratigraphy. The magnetostratigraphic age of 24.0 (22.9) m.y. falls within the range of radiometric dates for this boundary (Odin, 1978, p. 255).

The top of the Globorotalia opima opima Zone (P21), which is defined by the LAD of G. opima opima at Site 522 , coincides with the top of NP24 as indicated by Hardenbol and Berggren (1978). However, our age for this 
datum within Chron C-9-N is 28.9 (27.6) m.y., or some 2 or $3 \mathrm{~m} . \mathrm{y}$. older than the $26 \mathrm{~m}$.y. figure suggested by those authors, who placed the boundary in Chron C-7. They may have erred, because the systematic magnetostratigraphic investigation of the Paleogene by Lowrie and others also placed the boundary in Chron C-9-N.

The top of the Globigerina ampliapertura zone is tentatively defined by the FAD of Globorotalia opima opi$m a$; the uncertainty has resulted from the occurrence of specimens that show resemblances to G. opima opima at levels below the FAD. The magnetostratigraphic age is 32.7 (31.2) m.y.

The top of the Pseudohastigerina micra-Cassigerinella chipolensis zone is defined at Site 522 by the LAD of Pseudohastigerina spp. to fall within the early half of Chron C-12-R. Our determination placed the boundary at a level significantly older than the boundary suggested by Hardenbol and Berggren (Chron C-11).

The top of the Turborotalia cerroazulensis zone is the Oligocene/Eocene boundary in foraminiferal zonation. This datum has been recognized by the LAD of T. cerroazulensis near the top of Chron C-13-R, slightly above the top of NP20, which marks the epoch boundary according to nannofossils. This slight discrepancy has been noted in previous studies (see Hardenbol and Berggren, 1978). The magnetostratigraphic age of the foraminiferal boundary is 37.1 (35.5) m.y., or about 0.1 m.y. younger than the nannofossil boundary.

The top of the Globigerinatheka semiinvoluta zone is tentatively recognized by the $\mathrm{HO}$ of Globigerinatheka sp. aff. G. semiinvoluta in Hole 523, just above the top of Chron C-16-N. This magnetostratigraphic interpretation agrees with the conclusion reached by Lowrie and others on the Gubbio sequence. The magnetostratigraphic age is $39.0(37.5) \mathrm{m} . y$. Our correlation of foraminiferal-nannofossil stratigraphy differs from that recommended by Hardenbol and Berggren (see Fig. 1).

The sediments of the $T$. cerroazulensis and of $G$. semiinvoluta zones can be correlated with the Priabonian of Europe and with the Jackson Group of the Gulf Coast; Bolli's zones are also more or less equivalent to Blow's zones P17 to P15. Radiometric dating of foraminiferbearing Jackson sediments gave ages of 36.7 to 38.5 m.y. (Ghosh, cited by Hardenbol and Berggren, 1978, p. 229). The discrepancy between those dates and our magnetostratigraphic ages are not significant, and both sets are older than the age given by Glass and Crosbie (1982) for the microtektites in sediments of P16/P15 age in several DSDP holes.

The top of the Truncorotaloides rohri zone (P14) is recognized by secondary indicators (the LO of $G$. semiinvoluta, the HO of Acarinina spp.) in Hole 523, and it should be given a magnetostratigraphic age of $42(40) \pm$ $0.5 \mathrm{~m}$.y. (within the early half of Chron C-17). The top of the Turborotalia possagnoensis zone first proposed by Toumarkine and Bolli (1970) (and newly amended by these authors; pers. comm., 1982), is defined by the LADs of $T$. possagnoensis and $T$. frontosa. This newly defined zonal boundary should be equivalent to the top of P12 (the Morozovella lehneri zone). At Site 523 the LADs of the two marker species fall within Chron C-18-R2, almost synchronous to the LAD of the nanno- fossil species Chiasmolithus solitus (top of NP16) (see Poore et al., this vol., Fig. 6). The magnetostratigraphic age of the top of the $T$. possagnoensis zone is thus 43.4 (41.4) m.y. The top of the M. lehneri zone (P12), which is defined by the FAD of Orbulinoides beckmanni, occurs in C-18-N at Contessa, Italy, slightly below the corresponding level in Hole 523.

The sediments of the Claiborne Group that have yielded P14/P13 microfauna have radiometric ages ranging from 38.5 to $42.7 \mathrm{~m} . \mathrm{y}$. (Ghosh, cited by Hardenbol and Berggren, 1978). The revised glauconite age for the Barton beds of P14/P13 is $39.2 \mathrm{~m} . \mathrm{y}$. (Odin, 1978). The discrepancy between our magnetostratigraphic and their radiometric ages is not great. In fact, the alternate magnetostratigraphic age of $40 \mathrm{~m} . \mathrm{y}$. for the top of P14, which marks the boundary between the late and middle Eocene, is identical to the figure recommended by Hardenbol and Berggren (1978) and Pomerol (1978) for this epoch boundary.

The top of the $T$. frontosa zone is defined by the FAD of $T$. possagnoensis at about $180 \mathrm{~m}$ sub-bottom in Hole 523. The datum lies within the long interval of reversed magnetization of Chron C-20-R, and it has an estimated age of 49.4 (47.1) m.y. This marker horizon should fall within the Hantkenina aragonensis zone (P10), which, according to Hardenbol and Berggren (1978, p. 227), should have a radiometric age between $47.2 \mathrm{~m} . \mathrm{y}$. (for P12) and $52.0 \mathrm{~m} . \mathrm{y}$. (for P6). Again, we see no serious discrepancy between the magnetostratigraphic and isotope ages.

Early Eocene and late Paleocene foraminiferal zones were not recognized at the Leg 73 sites, because we did not have time to drill at a site that had been proposed for the investigation of this stratigraphic interval. The next older foraminiferal datum level is the LO of Planorotalites pseudomenardii, which marks the top of the foraminifer zone P3. The magnetostratigraphic age is 60.4 (57.6) m.y. Hardenbol and Berggren (1978, p. 227) cited radiometric ages of 57.9 and 58.0 m.y. for P3 sediments, and these dates are in agreement with our alternate magnetostratigraphic date. The correlation of the foraminifer zone P5 to the nannofossil zone NP9 at our site contradicts this observation at Paderno d'Adda, where $P$. pseudomenardii occurs in sediment of NP6 (Cita et al., 1968). Perhaps the LO of this species is not the FAD, because the range could have been truncated by dissolution.

The top of P2, which is defined by the FAD of $M$. angulata, and the top of P1, which is defined by the LAD of Globigerina daubjergensis, fall within Chrons C-26-R and C-27-R and have magnetostratigraphic ages of 63.7 (60.8) m.y. and 64.7 (61.8) m.y., respectively.

\section{CENOZOIC EPOCH BOUNDARIES}

The Pleistocene/Pliocene boundary, as defined by the FAD of Globorotalia truncatulinoides in the Leg 73 sites, falls within the Olduvai Event, with a magnetostratigraphic age of $1.8(1.7) \mathrm{m} . \mathrm{y}$. , in agreement with the current interpretation.

The Pliocene/Miocene boundary is not very precisely defined by the data from the Leg 73 drilling because of the dissolution of the Miocene sediments. The boundary 
is at a level near the Gilbert Epoch 5 boundary, and the LO of G. cibaoensis (latest Miocene) in a reversely magnetized sediment suggests that the biostratigraphic epoch boundary at $5.2(5.0) \mathrm{m} . \mathrm{y}$. is slightly younger than the magnetostratigraphic boundary. This conclusion is in agreement with the findings by Prell, Gartner, and others (1980, p. 438).

The Miocene/Oligocene boundary as defined by nannofossil zonation is slightly younger than that defined by the foraminiferal zonation, and the magnetostratigraphic ages are 23.8 (22.7) m.y. and 24.0 (22.9) m.y., respectively. These ages agree very well with estimated radiometric ages for this boundary, which have been variously estimated to range from $22.5 \mathrm{~m}$.y. (Berggren and Van Couvering, 1974) to 23 m.y. (Odin, 1978; Curry and Odin, 1982) to 24 m.y. (Hardenbol and Berggren, 1978).

The Oligocene/Eocene boundary as defined by nannofossil zonation is slightly older than that defined by the foraminiferal zonation; the respective magnetostratigraphic ages are $37.2(35.6) \mathrm{m} . \mathrm{y}$. and 37.1 (35.5) m.y. The age of this boundary, estimated on the basis of radiometric dating, is $37 \mathrm{~m}$.y. according to Hardenbol and Berggren (1978) and 35 m.y. according to Odin (1982) but only $32 \mathrm{~m} . \mathrm{y}$. according to Glass and Crosbie (1982). The magnetostratigraphic and radiometric ages are in general agreement, except that the last estimate is far too young. It should be pointed out that Glass and Crosbie's radiometric dates of microtektites from well defined biostratigraphic horizons have large analytic errors $( \pm 4 \mathrm{~m} . \mathrm{y}$.) and that the good radiometric data came from North American tektites, which have not been accurately placed biostratigraphically. The possibility of several different falls of tektites has been suggested (Bottomley, 1979). The microtektites from the Pacific piston cores are significantly younger than the iridium anomaly, the event markers for the impact (see Drake, 1982). If the tektites once formed a ring around the earth like Saturn's ring, as proposed by O'Keefe (1980), the tektites might indeed have fallen at somewhat different times.

The Eocene/Paleocene boundary lies within an uncored interval at Site 524. The magnetostratigraphic age should be 59.0 (55.4) $\pm 0.2 \mathrm{~m}$.y. The revised age is about the same as an older estimate of the radiometric age but significantly older than the $53 \mathrm{~m}$.y. proposed by Odin (1982).

The Cretaceous/Tertiary boundary is defined by the first appearance of several Tertiary nannofossil taxa and by the FAD of Globigerina eugubina with Chron C-29$\mathrm{R}$. The boundary at Site 524 has been investigated in detail and reported elsewhere (Hsu et al., 1982 and this vol.).

\section{CENOZOIC SEAFLOOR SPREADING RATE}

The magnetostratigraphic ages of the biostratigraphic zones calculated on the basis of assuming a maximum of $66.5 \mathrm{~m} . \mathrm{y}$. or a minimum of $63.5 \mathrm{~m} . \mathrm{y}$. for the age of the Cenozoic are plotted against their radiometric ages in Figure 2. If the rate of seafloor spreading has been linear, the ages should plot along a straight line at $45^{\circ}$ from both axes. Deviations from the straight-line relationship could result from (1) errors in radiometric dating, (2) errors in the bio- and/or magnetostratigraphic interpretations, and (3) true deviations from a linear seafloor spreading rate.

The agreement for the last 5 m.y. (Datum Levels A, B, C, and D, Fig. 2) is satisfactory (Berggren and Van Couvering, 1974; Ryan et al., 1974). Our new results confirm, on the whole, previous interpretations for this time interval.

Two points that deviate significantly from the straight line are the dates for the middle Miocene nannofossil zones NN8 and NN6. Errors in radiometric dating and/ or stratigraphic interpretations cannot be completely ruled out, but the repeated presence of middle Miocene sediments (NN6 at Site 396 and NN8 at Sites 519 and 521 ) with radiometric ages of 11 to $13 \mathrm{~m} . \mathrm{y}$. (Anomaly 5, on supposedly upper Miocene crust with magnetostratigraphic ages of 9-10 m.y.) suggests that the seafloor spreading rate may have been anomalous during the middle Miocene.

The agreement of the middle Cenozoic datum levels (the Orbulina datum at 15-16 m.y., the Miocene/Oligocene boundary at 23-24 m.y., and the Oligocene/Eocene boundary at 35-37 m.y.) validates the assumption of a linear spreading rate, except for the questionable microtektite dates.

The Eocene and late Paleocene data are not unequivocal, however. The radiometric dates of foraminiferbearing sediments, especially those from the Gulf Coast Jackson and Claiborne groups, agree on the whole with our revised magnetostratigraphic ages. However, the new $\mathrm{K} / \mathrm{Ar}$ ages of the glauconites in the nannofossil sediments of Europe by Odin are consistently younger than both of our sets of magnetostratigraphic ages. The discrepancy is particularly large for the early Eocene/late Paleocene interval. We have to keep open the question of a nonlinear spreading rate during that time.

The early Paleocene radiometric dates are more in accord with the younger (alternate) magnetostratigraphic ages, yet the $63.5 \mathrm{~m} . y$. age by Lerbekmo and others for the beginning of the Cenozoic is probably too young (Berggren, pers. comm., 1982). The most probable age for this datum is $65 \mathrm{~m}$.y. If so, the numerical ages cited in this report for the various zones may represent the maximum and minimum age ranges.

\section{REFERENCES}

Berggren, W. A., and Van Couvering, J. A., 1974. The late Neogene. Palaeogeogr. Palaeoclimatol. Palaeoecol., 16:1-216.

Blow, W. H., 1969. Late middle Eocene to recent planktonic foraminiferal biostratigraphy. In Brönnimann, P., and Renz, H. H. (Eds.), First Planktonic Conf.: Leiden (Brill), pp. 199-421. 1979. The Cenozoic Globigerinida: Leiden (Brill).

Bolli, H. M., 1966. Zonation of Cretaceous to Pliocene marine sediments based on planktonic foraminifera. Bol. Inf. Asoc. Venez. Geol. Min. Pet., 9:3-32.

Bottomley, R. J., York, D., and Grieve, R. A. F., 1979. Possible source craters for the North American tektites-a geochronological investigation. Trans. Am. Geophys. Union, 60:309.

Bukry, D. 1979. Neogene coccolith stratigraphy, Mid-Atlantic Ridge, Deep Sea Drilling Project Leg 45. In Melson, W. G., Rabinowitz, P. D., et al., Init. Repts. DSDP, 45: Washington (U.S. Govt. Printing Office), 307-318. 
Cita, M. B., et al., 1968. Le Paleocène et l'Eocène de Paderno d'Adda (Italie Septentrionale). Colloque sur l'Eocène (Paris), pp. 611-627.

Curry, D., and Odin, G. S., 1982. Dating of the Paleogene. In Odin, G. S. (Ed.), Numerical Dating in Stratigraphy: New York (John Wiley \& Sons), pp. 603-630.

Drake, C., 1982. Impacts and evolution conference: comment. Geology, 10:127-138.

Dymond, J. R., 1966. Potassium-argon geochronology of deep sea sediments. Science, 152:1239-1241.

Foster, J. H., and Opdyke, N. D., 1970. Upper Miocene to recent magnetic stratigraphy in deep-sea sediments. J. Geophys. Res., 75: 4464-4473.

Gartner, S., 1973. Absolute chronology of the late Neogene calcareous nannofossil succession in the equatorial Pacific. Geol. Soc. Am. Bull., 84:2021-2033.

Glass, B. P., and Crosbie, J. R., 1982. Age of Eocene/Oligocene boundary based on extrapolation from North American microtektite layer. Am. Assoc. Pet. Geol. Bull., 66:471-476.

Gramann, F., Harre, W., Kreuzer, H., Look, E. R., and Mattiat, B., 1975. K-Ar-ages of Eocene to Oligocene glauconitic sands from Helmstedt and Lehrte (Northwestern Germany). Newsl. Stratigraphy, 4:71-86.

Hardenbol, J., and Berggren, W. A., 1978. A new Paleogene numerical time-scale. Stud. Geol. Tulsa Okla. No. 6, pp. 205-212.

Hsü, K. J., He, Q., McKenzie, J. A., Weissert, H., Perch-Nielsen, K., Oberhansli, H., Kelts, K., LaBrecque, J., Tauxe, L., Krahenbuhl, U., Percival, S. F., Wright, R., Karpoff, A., Petersen, N., Tucker, P., Poore, R., Gombos, A., Pisciotto, K., Carman, M. F., Schreiber, E., 1982. Mass mortality and its environmental and evolutionary consequences. Science, 216:249-256.

Ikebe, N. Takayanagi, Y., Chiji, M., and Chinzeik, K., 1972. Neogene biostratigraphy and radiometric time-scale of Japan. Pac. Geol., 5:39-78.

Jenkins, D. G., 1978. Neogene planktonic foraminifers from DSDP Leg 40 Sites 360 and 362 in the southeastern Atlantic. In Bolli, H. M., Ryan, W. B. F., et al., Init. Repts. DSDP, 40: Washington (U.S. Govt. Printing Office), 723-740.

Kennett, J. P., 1973. Middle and late Cenozoic planktonic foraminiferal biostratigraphy of the southwest Pacific-DSDP, Leg 21. In Burns, R. E., Andrews, J. E., et al., Init. Repts. DSDP, 21: Washington (U.S. Govt. Printing Office), 575-640.

Kennett, J. P., and Watkins, N. D., 1972. The biostratigraphic, climatic, and paleomagnetic record of late Miocene to early Pleistocene sediments of New Zealand. 24th Int. Geol. Congr. (Montreal), p. 538. (Abstract)

LaBrecque, J. L., Kent, D. V., and Cande, S. C., 1977. Revised magnetic polarity time scale for late Cretaceous and Cenozoic time. Geology, 5:330-335.

Lerbekmo, J. F., Evans, M. E., and Baardsgaard, H., 1979. Magnetostratigraphy, biostratigraphy, and geochronology of CretaceousTertiary boundary sediments, Red Deer Valley. Nature, 279:26-30.

Lowrie, W., Alvarez, W., Napoleone, G., Perch-Nielsen, K., Premoli Silva, I., and Toumarkine, M., 1982. Paleogene magnetic stratigraphy in Umbrian pelagic carbonate rocks, the Contessa sections, Gubbio. Geol. Soc. Am. Bull., 93:414-432.

McDougall, I., and Page, R. W., 1975. Toward a physical time-scale for the Neogene-data from the Australian region. Micropaleontology Spec. Publ. No. 1, pp. 75-84.
Martini, E., 1971. Standard Tertiary and Quaternary calcareous nannoplankton zonation. In Farinacci, A. (Ed.), Proc. Second Planktonic Conf.: Rome (Tecnoscienza), pp. 739-786.

Maxwell, A. E., Von Herzen, R. P., et al., 1970. Init. Repts. DSDP, 3: Washington (U.S. Govt. Printing Office).

Maxwell, A. E., Von Herzen, R. P., and Shipboard Scientific Party, 1970. Summary and conclusions. In Maxwell, A. E., Von Herzen, R. P., et al., Init. Repts. DSDP, 3: Washington (U.S. Govt. Printing Office), 441-471.

Odin, G. S., 1975. Les glauconies-constitution, formation, age [These Dott. Etat]. Paris, France.

1978. Isotopic dates for a Paleogene time scale. Stud. Geol. Tulsa Okla. No. 6, pp. 247-257.

Odin, G. S., and Curry, D., 1981. L'échelle numérique des temps paléogènes en 1981. C.R. Acad. Sci. Paris, 293(Ser. II):1003-1006.

O'Keefe, J. A., 1980. The terminal Eocene event-formation of a ring system around the Earth. Nature, 285:309-311.

Opdyke, N. D., Lindsay, E., Johnson, G. D., Johnson, N., Tahirkheli, R. A. K., and Mirza, M. A., 1979. Magnetic polarity stratigraphy and vertebrate paleontology of the Upper Siwalik Subgroup of Northern Pakistan. Paleogeogr. Palaeoclimatol. Palaeoecol., 27: 1-34.

Pomerol, C., 1978. Critical review of isotopic dates in relation to $\mathrm{Pa}-$ leogene stratotypes. Stud. Geol. Tulsa Okla. No. 6, pp. 235-245.

Prell, W. L., Gartner, J. V., et al., 1980. Hydraulic piston coring of late Neogene and Quaternary sections in the Caribbean and equatorial Pacific: preliminary results of Deep Sea Drilling Project Leg 68. Geol. Soc. Am. Bull., 91:433-444.

Purdy, G. M., Rabinowitz, P. D., and Schouten, H., 1979. The MidAtlantic Ridge at $23^{\circ} \mathrm{N}$ : bathymetry and magnetics. In Melson, W. G., Rabinowitz, P. D., et al., Init. Repts. DSDP, 45: Washington (U.S. Govt. Printing Office), 119-128.

Ryan, W. B. F., Cita, M. B., Dreyfus, M., Burckle, L. H., and Saito, T., 1974. A paleomagnetic assignment of Neogene stage boundaries and the development of isochronous datum plans between the Mediterranean, the Pacific, and Indian oceans. Riv. Ital. Paleontol., 80:631-688.

Saito, T., Burckle, L. H., and Hays, J. D., 1975. Late Miocene to Pleistocene biostratigraphy equatorial Pacific sediments. Micropaleontology Spec. Publ. No. 1, pp. 226-244.

Salvatorini, G., and Cita, M. B., 1979. Miocene foraminiferal stratigraphy, DSDP Site 397 (Cape Bojador, North Atlantic). In von Rad, U., Ryan, W. B. F., et al., Init. Repts. DSDP, 47, Pt. 1: Washington (U.S. Govt. Printing Office), 317-374.

Stainforth, R. M., et al., 1975. Cenozoic planktonic foraminiferal zonation and characteristics of index forms. Univ. Kansas Paleontol. Contrib. Pap., 62:1-425.

Supko, P. R., Perch-Nielsen, K., et al., Init. Repts. DSDP, 39: Washington (U.S. Govt. Printing Office).

Tauxe, L., 1979. A new date for Ramapithecus. Nature, 282:399-401.

Theyer, F., and Hammond, S. R., 1974. Cenozoic magnetic time scale in deep-sea cores: completion of the Neogene. Geology, 2: 487-492.

Toumarkine, M., and Bolli, H. M., 1970. Evolution de Globorotalia cerroazulensis (Cole) dans l'éočene moyen et supérieur de Possagno (Italie). Rev. Micropaleontol., 13:131-145.

Date of Initial Receipt: October 26, 1982 


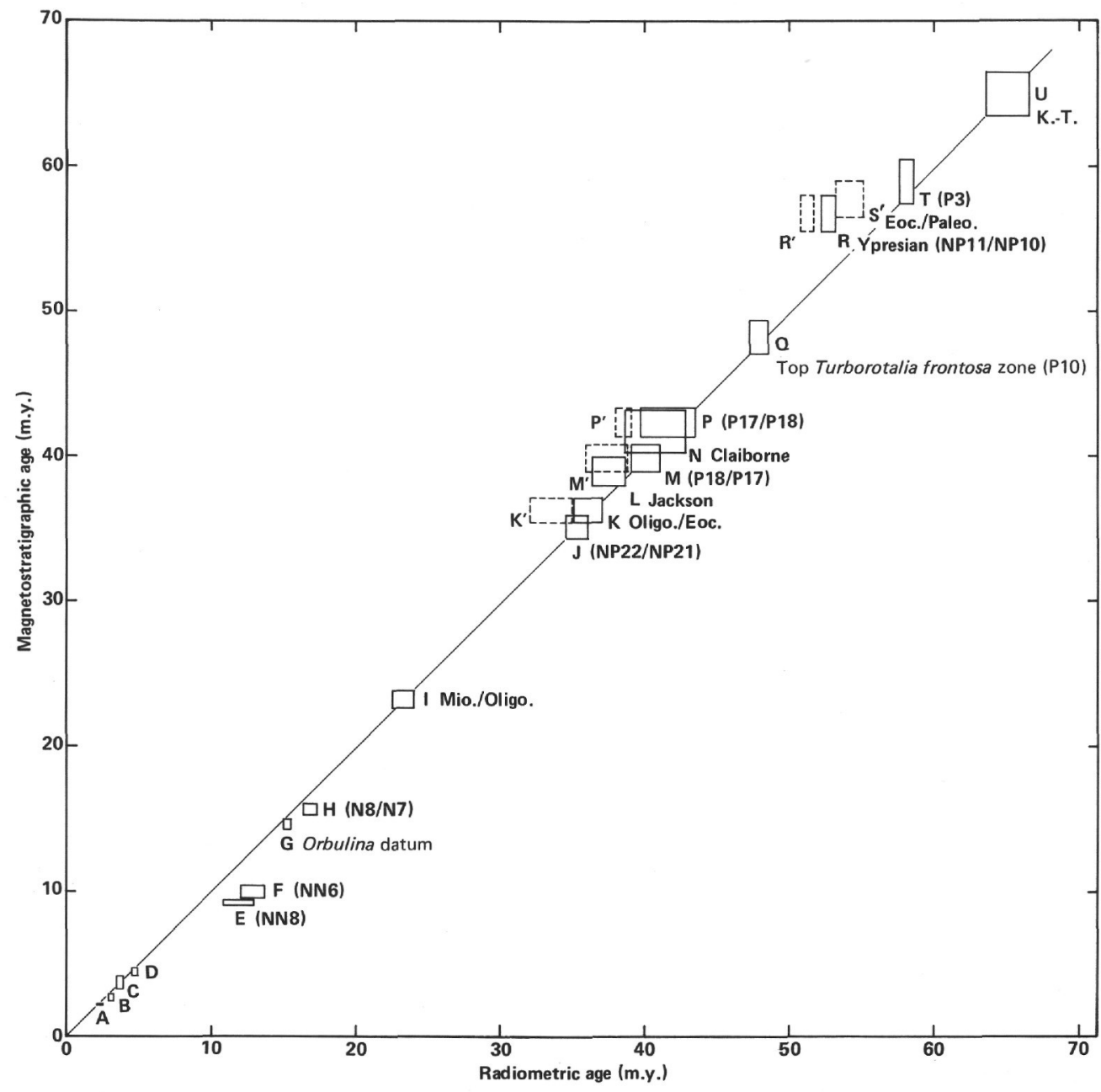

Figure 2. Correlation of magnetostratigraphic and radiometric ages. Points A to D are taken from Ryan et al. (1974). The other datum levels have been dated magnetostratigraphically by us and radiometrically by previous authors. Datum levels indicated by dashes and given primed letter designations (e.g., $K^{\prime}$ ) have the radiometric ages obtained by Odin (1978), which differ greatly from the magnetostratigraphic ages found by us and the radiometric ages found by other authors. The data from the middle Miocene (Levels $\mathrm{E}$ and $\mathrm{F}$ ) and the Eocene-Paleocene (Levels $\mathrm{R}$ and S) are discordant enough to suggest nonlinear seafloor spreading rates during those times. 